
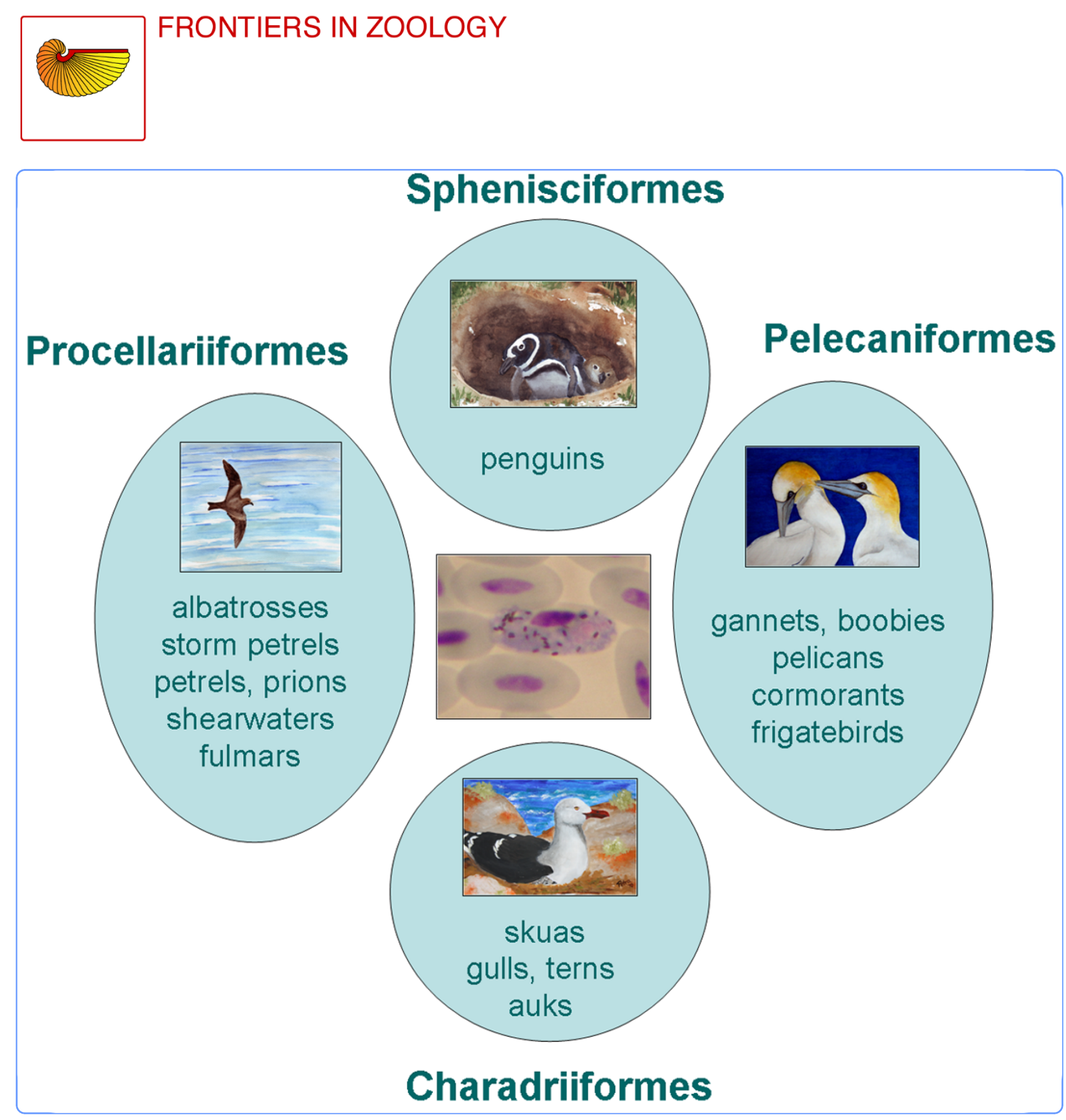

\title{
Prevalence of blood parasites in seabirds - a review
}

Quillfeldt et al. 


\title{
Prevalence of blood parasites in seabirds - a review
}

Petra Quillfeldt ${ }^{*}$, Elena Arriero', Javier Martínez ${ }^{2}$, Juan F Masello ${ }^{1}$ and Santiago Merino ${ }^{3}$

\begin{abstract}
Introduction: While blood parasites are common in many birds in the wild, some groups seem to be much less affected. Seabirds, in particular, have often been reported free from blood parasites, even in the presence of potential vectors.

Results: From a literature review of hemosporidian prevalence in seabirds, we collated a dataset of 60 species, in which at least 15 individuals had been examined. These data were included in phylogenetically controlled statistical analyses of hemosporidian prevalence in relation to ecological and life-history parameters. Haemoproteus parasites were common in frigatebirds and gulls, while Hepatozoon occurred in albatrosses and storm petrels, and Plasmodium mainly in penguins. The prevalence of Haemoproteus showed a geographical signal, being lower in species with distribution towards polar environments. Interspecific differences in Plasmodium prevalence were explained by variables that relate to the exposure to parasites, suggesting that prevalence is higher in burrow nesters with long fledgling periods. Measures of Plasmodium, but not Haemoproteus prevalences were influenced by the method, with PCR-based data resulting in higher prevalence estimates.

Conclusions: Our analyses suggest that, as in other avian taxa, phylogenetic, ecological and life-history parameters determine the prevalence of hemosporidian parasites in seabirds. We discuss how these relationships should be further explored in future studies.
\end{abstract}

\section{Introduction}

Birds are infected by a number of intracellular blood parasites, including Haemosporidia of the genera Plasmodium, Haemoproteus and Leucocytozoon, Haemogregarinidae of the genus Hepatozoon and Piroplasmida of the genus Babesia. These blood parasites can exert important selection pressure on their hosts through effects on survival [1-3], on reproductive success [e.g., [4-8]], on plumage colouration [e.g., [9,10]], with important ecological and evolutionary consequences, such as changes in community structure [e.g., [11]].

The rate of infection varies greatly among different bird orders [e.g., $[12,13]]$, but the reasons for the wide taxonomic variation in parasite prevalence or diversity are still poorly understood $[14,15]$. While some avian taxa are heavily affected, apparent absence or scarcity of blood parasites has been reported from others [see

\footnotetext{
* Correspondence: petra.quillfeldt@gmx.de

'Max-Planck-Institut für Ornithologie, Vogelwarte Radolfzell, Schlossallee 2,

78315 Radolfzell, Germany

Full list of author information is available at the end of the article
}

$[16,17]]$, especially in avian groups such as seabirds [e.g., [18-22]], swifts [23], waders [24] and parrots [25].

In addition to the apparent phylogenetic bias in the incidence of parasitic infections among bird taxa, there is also some evidence that blood parasites are less common in certain habitats such as the Arctic tundra [e.g., [26]], arid environments [e.g., [27,28]], island environments [e.g.,[29]] or marine environments [e.g., [30-32]]. Several hypotheses have been proposed to explain this absence [16], such as the absence or scarcity of proper vectors, a highly specific association between host and parasites with host switching being infrequent (hostparasite assemblage), host immunological capabilities preventing infection by parasites, and competitive exclusion of blood parasite vectors mediated by ectoparasites.

A number of comparative studies have analysed patterns of blood parasite prevalence across bird taxa, with the aim to understand how the selection pressure from parasitism is linked to ecological and evolutionary traits of their hosts [e.g. [3,14,15,33]]. In the present study, we review information on blood parasites in seabirds. Using
Ciomed Central

() 2011 Quillfeldt et al; licensee BioMed Central Ltd. This is an Open Access article distributed under the terms of the Creative Commons Attribution License (http://creativecommons.org/licenses/by/2.0), which permits unrestricted use, distribution, and reproduction in any medium, provided the original work is properly cited. 
phylogenetically controlled statistical analyses we tested if blood parasite prevalence in seabirds is related to the following factors: 1) historical/phylogenetic factors, 2) life history parameters, and 3) ecological parameters.

\section{Results}

\section{Literature review}

From the 113 seabird species listed in Table 1, parasitic infections by hematozoa were found in 31 species (27\%). This was similar to the percentage of infected species reported in 60 species with at least 15 individuals sampled (20 species or $33 \%, \chi^{2}=0.18$ d.f. $1, P=0.669$ ). The prevalence of multiple infections was very low, as only five host species were reported infected by more than one parasite genus (Additional file 1: Table S1): Fjordland crested penguin Eudyptes pachyrhynchus (2), little penguin Eudyptula minor (2), African penguin Spheniscus demersus (3), magnificent frigatebird Fregata magnificens (2) and yellow-legged gull Larus cachinnans (2). The other 25 species in which infections were found only had a single kind of parasite. The proportion of species infected differed between bird families (Table 1), from complete absence in some groups such as cormorants (7 species studied), skuas ( 5 species) and auks (3 species) to $100 \%$ of species and populations infected in frigatebirds (4 species studied so far). The average prevalence of haematozoa across all studies here reported ( $N=231$ studies, or 6,656 adults and 1,143 chicks, see
Additional file 1: Table S1) was $8.5 \%$ (blood smears, PCR and ELISA combined) or 5.7\% (based on blood smears only).

The occurrence of haemoparasites increased from polar to tropical seabirds $\left(\chi^{2}=10.6, d . f .=3, P=0.031\right)$. Blood parasites were absent from Antarctic and arctic seabirds $(N=15$ species). In the Sub-Antarctic islands, 5 of 21 seabird species (24\%) studied were found to have haemoparasites, while 18 of 57 temperate seabird species (32\%) and 11 of 25 tropical seabirds (44\%) had at least one record (see Additional file 1).

\section{Phylogenetically controlled analysis}

Figure 1 shows phylogenetic associations among species in the study and the information on the presence of parasites for those species. Even though visual inspection suggests phylogenetic clustering of the incidence of parasitism among the different taxa of seabirds (Figure 1 ), the results of the phylogenetic autoregression analyses did not support this, as interspecific variation in parasite prevalence of the main genera of haematozoa was not explained by phylogenetic associations among species (Haemoproteus: rho $=-0.13, P=0.292$; Plasmodium: rho $=-0.21, P=0.649 ;$ Hepatozoon: $\mathrm{rho}=-1.52$, $P=0.729)$. Due to the low prevalence, it was not possible to include Babesia in this analysis.

We included the two most commonly observed parasites (Plasmodium, Haemoproteus) into phylogenetically

Table 1 Seabird families, sorted by increasing parasite prevalence

\begin{tabular}{|c|c|c|c|c|c|c|c|c|}
\hline $\begin{array}{l}\text { Family (no. } \\
\text { species) }\end{array}$ & $\begin{array}{l}\text { species } \\
\text { studied }\end{array}$ & $\begin{array}{l}\text { species } \\
\text { infected }\end{array}$ & $\begin{array}{l}\text { Mean prevalence } \\
\text { (no. studies) }\end{array}$ & Plasmodium & Haemoproteus & Leucozytozoon & Hepatozoon & Babesia \\
\hline Pelecanoididae (4) & $1(25 \%)$ & 0 & $0(N=1)$ & - & - & - & - & - \\
\hline Phaethontidae (3) & $3(100 \%)$ & 0 & $0(N=7)$ & - & - & - & - & - \\
\hline Pelecanidae (8) & $1(13 \%)$ & 0 & $0(N=2)$ & - & - & - & - & - \\
\hline Stercorariidae (7) & $5(71 \%)$ & 0 & $0(N=8)$ & - & - & - & - & - \\
\hline Alcidae (22) & $3(14 \%)$ & 0 & $0(N=4)$ & - & - & - & - & - \\
\hline Procellariidae (72) & $16(22 \%)$ & $2(12 \%)$ & $0.1 \%(N=28)$ & P. sp. (2) & - & - & - & - \\
\hline $\begin{array}{l}\text { Phalacrocoracidae } \\
\text { (32) }\end{array}$ & $8(25 \%)$ & $1(12 \%)$ & $1.3 \%(\mathrm{~N}=13)$ & - & - & $\begin{array}{l}\text { L. vanden- } \\
\text { brandeni (1) }\end{array}$ & - & - \\
\hline Hydrobatidae (20) & $4(20 \%)$ & $1(25 \%)$ & $3.3 \%(N=6)$ & - & - & - & H. sp. (1) & - \\
\hline Spheniscidae (19) & 19 (100\%) & $6(32 \%)$ & $14.4 \%(\mathrm{~N}=64)$ & $\begin{array}{l}\text { P. relictum (5), } \\
\text { P. sp. (1) }\end{array}$ & - & L. tawaki (2) & - & $\begin{array}{l}\text { B. peircel } \\
\text { (2) }\end{array}$ \\
\hline Sulidae (10) & $6(60 \%)$ & $2(33 \%)$ & $7.1 \%(N=12)$ & - & H. sp. (1) & - & - & $\begin{array}{l}\text { B. poeled } \\
\quad(2), \\
\text { B. sp. (1) }\end{array}$ \\
\hline Diomedeidae (14) & $7(50 \%)$ & $4(57 \%)$ & $7.8 \%(N=14)$ & - & - & - & $\begin{array}{l}\text { H. albatrossi } \\
\text { (4) }\end{array}$ & - \\
\hline Lariidae (92) & $36(18 \%)$ & 7 (59\%) & $9.2 \%(N=59)$ & P. sp. (1) & $\begin{array}{l}\text { H. larae (5), } \\
\text { H. passeris (1), } \\
\text { H. sp. (4) }\end{array}$ & - & - & $\begin{array}{c}B . \\
\text { bennetti } \\
(1)\end{array}$ \\
\hline Fregatidae (5) & $4(80 \%)$ & $4(100 \%)$ & $27.7 \%(N=7)$ & - & $\begin{array}{l}\text { H. iwa (3), } \\
\text { H. sp. (1) }\end{array}$ & - & - & - \\
\hline All seabirds (453) & $113(25 \%)$ & 31 (27\%) & $8.4 \%(N=224)$ & $\geq 1$ spp. & $\geq 3$ spp. & 1 spp. & $\geq 1$ spp. & $\geq 3 \mathrm{spp}$. \\
\hline
\end{tabular}

Species infected as percentage of species studied. No data were found for sheathbills Chionididae (2 species) and skimmers Rynchopidae ( 3 species). For details and sources, see Table S1 in Additional file 1. 


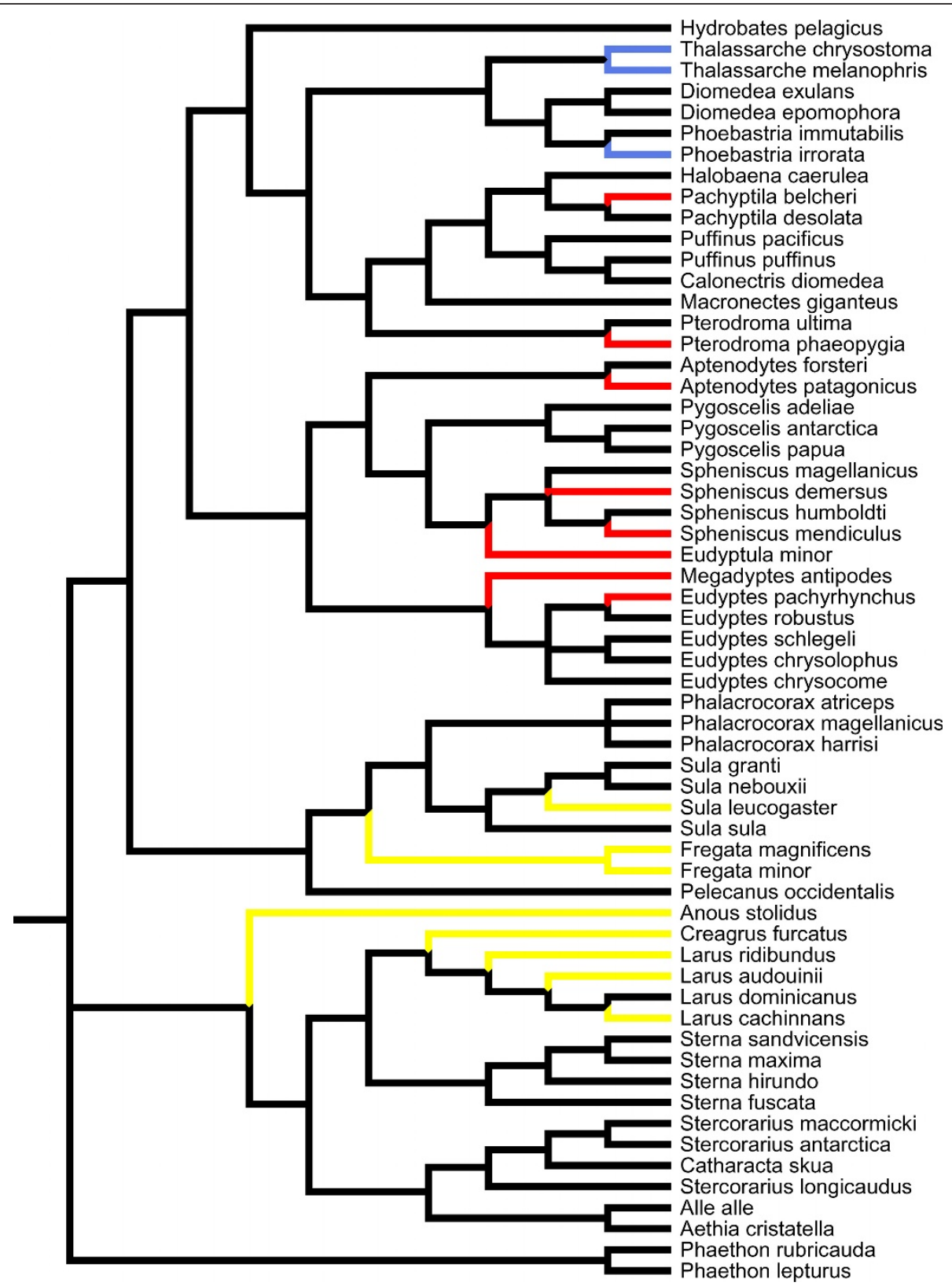

Figure 1 Phylogeny of seabird species and hemoparasite infections. The clasification includes species for which at least 15 individuals have been sampled for blood parasites, using blood smears or molecular methods. Colour marked are those species which were found to be infected with Hepatozoon (blue), Plasmodium (red) and Haemoproteus (yellow). The apparent phylogenetic clustering was, however, not statistically significant.

controlled analyses of hemosporidian prevalence in relation to ecological and life-history parameters. Given their low prevalence, it was not possible to include blood parasites from genera Hepatozoon and Babesia in this analysis.

Inter-specific differences in Plasmodium infections were explained by variables that relate to the exposure to parasites, suggesting that burrow nesters and species with longer nestling periods were more likely to harbour
Plasmodium (Table 2), and the Plasmodium prevalence was also higher in burrow nesters. Method had a significant influence on the proportion of infected individuals detected, with higher prevalences for PCR-based data (Table 2).

The presence/absence of infections by Haemoproteus was not associated with any of the ecological or life history parameters considered in the study. However, a latitudinal trend was observed in the proportion of 
Table 2 Parameter estimates of phylogenetically informed GLS models and GEE models for Plasmodium

\begin{tabular}{|c|c|c|}
\hline Variables in best-fit model & $\begin{array}{c}\text { Prevalence (GLS) } \\
\mathrm{N}=60 \mathrm{spp} . \text { (PCR data included, method included in model) }\end{array}$ & $\begin{array}{c}\text { Presence/absence (GEE) } \\
\mathrm{N}=60 \text { spp. (PCR data included) }\end{array}$ \\
\hline \multicolumn{3}{|l|}{ Ecological parameters } \\
\hline Nesting (burrow $=1$, others $=0$ ) & $0.063 \pm 0.026, P=0.018$ & $3.408 \pm 0.977, P=0.004$ \\
\hline Foraging ( $0=$ nearshore, $2=$ offshore) & $-0.014 \pm 0.014, P=0.301$ & \\
\hline \multicolumn{3}{|l|}{ Life-history parameters } \\
\hline Mean fledging period (days) & $0.042 \pm 0.060, P=0.490$ & $5.949 \pm 2.045, P=0.011$ \\
\hline Method (smears or PCR) & $0.051 \pm 0.018, P=0.006$ & \\
\hline
\end{tabular}

Means \pm s.e. are given. Only variables retained in the best-fit models are presented in the table. Excluded variables: body mass, chick development, maximum clutch size, mean incubation period, distribution

individuals infected by Haemoproteus (i.e. prevalence), with higher number of individuals infected in species with tropical distribution (Table 3). Method did not influence measured Haemoproteus prevalences (Table 3).

\section{Discussion}

In the present study, we summarize the available information on the prevalence of haematozoa of the genera Plasmodium, Haemoproteus, Leucocytozoon, Hepatozoon and Babesia in seabirds. As previously suggested [e.g., [18-21]], our review underlines that in general, the incidence of blood parasitic infections is low in seabirds (Table 1 Additional file 1). The average prevalence of haematozoa across all seabird species studied (Additional file 1: Table S1) was $8.7 \%$, compared to $26 \%$ in a sample of 14,812 European passerines [14].

\section{Blood parasites and climate}

Blood parasites were absent from all Antarctic and arctic seabirds, and the occurrence increased in milder climates. This finding is in line with previous studies [34] that noted that blood parasites present in sub-Antarctic islands were absent in Antarctica and suggested that this mirrors the absence of suitable vectors in Antarctica [19]. Latitudinal gradients in the prevalence of blood parasites have also been found in other bird species [e.g. [35]], and even in within-species patterns. For example, shorebirds migrating through Europe were free from infections while their conspecifics did show infections in tropical Africa [36].
Haematozoa are transmitted to their vertebrate host through arthropod vectors. Although still a great deal of data about the biology and ecology of various vector species is missing, some authors have suggested that the limit of the distribution of vectors such as mosquitos and sandflies corresponds to the $10^{\circ} \mathrm{C}$ annual isotherm [e.g., [37]]. Furthermore, for species that hibernate at the larval stage, the $-1^{\circ} \mathrm{C}$ winter isotherm is decisive for their distribution since larvae that freeze do not survive. Thus, vectors would be absent at high latitudes, and more common with higher temperatures, and this is reflected in the distribution of blood parasites in the seabird hosts. Within genera, the present analysis suggested that the prevalence, i.e. the percentage of individuals infected with Haemoproteus, was higher in species in more tropical environments, but this was not the case for Plasmodium. Given the relatively low detection probability of Plasmodium based on blood smears, it is possible that a geographical pattern is not apparent unless more PCR based studies are undertaken. But differences in the biology of the vectors might also explain this difference in the distributon of Haemoproteus and Plasmodium. While Plasmodium is transferred by mosquitoes (Culicidae) and, at least in reptiles, also by sandflies (Psychodidae), Haemoproteus is transferred by louse flies (Hippoboscidae) and biting midges (Ceratopogonidae). Some studies have shown an important effect of temperature on activity and host location by these insects [see [38,39]]. However, the identity of vectors is unknown in most avian and, to our knowledge, all

Table 3 Parameter estimates of phylogenetically informed GLS models and GEE models for Haemoproteus

\begin{tabular}{|c|c|c|}
\hline Variables in best-fit model & $\begin{array}{c}\text { Prevalence (GLS) } \\
\mathrm{N}=60 \text { spp. (PCR data included, method included in model) }\end{array}$ & $\begin{array}{c}\text { Presence/absence (GEE) } \\
\mathrm{N}=60 \text { spp. (PCR data included) }\end{array}$ \\
\hline \multicolumn{3}{|l|}{ Ecological parameters } \\
\hline Distribution $(1=$ polar, $9=$ tropical $)$ & $0.023 \pm 0.010, P=0.025$ & $0.287 \pm 0.209, P=0.191$ \\
\hline \multicolumn{3}{|l|}{ Life-history parameters } \\
\hline Mean fledging period (days) & $-0.128 \pm 0.155, P=0.413$ & $-1.389 \pm 2.00, P=0.499$ \\
\hline Method (smears or $P C R$ ) & $-0.013 \pm 0.049, P=0.786$ & \\
\hline
\end{tabular}

Means \pm s.e. are given. Only variables retained in the best-fit models are presented in the table. Excluded variables: Body mass, Nest site, Foraging, chick development, Maximum clutch size, Mean incubation period 
seabird studies, and we can expect better insight into parasite distribution from studies of arthropod vectors. For example, ticks (Ixodidae) were generally thought to be the vector for Hepatozoon, but one study indicated that fleas can also serve as a vector [40].

\section{Blood parasites and seabird phylogeny}

The most common parasites found in seabirds were Haemoproteus and Plasmodium (Additional file 1: Table S1), similar to passeriformes [14]. Hepatozoon occurred in albatrosses and storm petrels, and Plasmodium mainly in penguins, while Haemoproteus were especially common in frigatebirds and gulls (Table 1). In this context, it may be relevant that many gulls are adapted to exploiting inland and human-modified or urban environments. These environments may harbour a higher vector density than saline environments [31]. However, the apparent difference among seabird families, though not statistically significant, also suggests a role of immunocompetence in preventing Haemoproteus infection in marine birds [16]. This possibility should be analyzed again when data of more seabird species become available. Babesia was found in different unrelated seabird species, suggesting the possibility that these infections result from several independent colonization events [e.g. [41]].

\section{Blood parasites and life-history parameters}

In line with the finding that avian Plasmodium and their vectors are distributed worldwide except in extreme habitats [12], the occurrence and prevalence of Plasmodium infections was independent from the host distribution. However, inter-specific differences were explained by life-history variables that relate to the exposure to parasites, with Plasmodium occurrence and prevalence being higher in burrow nesters and occurrence also in seabirds with long nestling periods (Table 3).

Studies in other avian taxa have also suggested that exposure time to vectors is the main factor explaining differences in malaria prevalence: Similar to the present results, parasite species richness in 263 bird species from the Western Palearctic was positively associated with the duration of the nestling period [15]. Moreover, the Plasmodium prevalence was associated with the duration of the nestling period [15]. All these data may be indicative of the need of a long exposure time to vectors in nests to allow infection by Plasmodium and/or that infections by this parasite occur mainly during nestling stage or nest attending activities.

Moreover, adult shorebirds also showed higher malaria prevalence, suggesting that infection probability increases with cumulative exposure [36]. This is also partially supported by the non-significant tendency for infections being more frequent in birds foraging near- shore, as those expending more time in the vicinity of land are probably more exposed to vectors. Habitat features related to vector availability are also important, and have been used to explain higher or lower blood parasite prevalences in species breeding in forested habitats $[33,35,42]$.

We here found breeding habitat type (burrow) and exposure time at the nest (fledging period) explaining variation in Plasmodium but not Haemoproteus infections. This might reflect the habitat needs for the different vectors such as mosquitoes (Culicidae) and sandflies (Psychodidae) for Plasmodium and louse flies (Hippoboscidae) and biting midges (Ceratopogonidae) in Haemoproteus. For example, sandfly larvae often inhabit damp places containing organic matter such as cracks in walls or rock and animal burrows, where they feed on dead organic matter. Adults are blood suckers, but to our knowledge, the actual vectors for Plasmodium infections in seabirds are not known, and other arthropod larvae might have similar habitat requirements. The present analysis therefore strongly suggests that the vectors of seabird blood parasites deserve further study if we are to understand distribution patterns.

Previous phylogenetically controlled comparative studies have further identified body mass $[14,15,43]$ and embryonic development period [15,33] as explanatory variables for parasite prevalence. The latter might be due to enhanced immune performance in more slowly developing birds with longer embryonic development periods [44]. Although no such relationship was found in the present study, the overall low prevalence across the generally long-lived, slowly developing seabird taxa strongly suggests that such a mechanism also works in seabirds. It should also be noted that the relationship was not found for any parasite genus analysed separately in Western Paleartic birds [15].

Slightly different variables enter in the best-fit models predicting interspecific variation in parasite impact in seabirds, when the dependent variable is parasite prevalence (continuous variable) or the presence/absence of infections (categorical variable). These differences might be due to the fact that the analyses with the variable presence/absence ignore variation among infected species (as they are all scored as 1), and also stress the need for more data to obtain more robust patterns across species. Alternatively, the differences might be explained by traits concerning the life cycle of blood parasites or their vectors, which deserve more study.

\section{Conclusions}

In summary, seabirds are long-lived with a relatively slow-life history and low rates of haemoparasite infection. Partly owing to the scarcity of infection, no comparative information on parasite prevalences had been 
reported so far for most seabird taxa. The present results show that multiple factors are responsible for patterns of association between parasitic infections and ecological and life history traits in seabirds. Life history parameters and ecological parameters that show some correlation with parasite abundance seem to be associated to the abundance and/or life cycle requirements of specific vectors. The findings on nesting habitat and exposure time, in particular, are well in line with studies across avian taxa. To better understand the underlying ecological relationships, however, efforts are now needed to identify the arthropod vectors and gain a better knowledge of their distribution and biology.

Historical/phylogenetic factors also play a role, as indicated by the high prevalence of Haemoproteus in gulls and frigatebirds, the apparent confinement of Hepatozoon to albatross and storm-petrel species, and the high prevalence of Plasmodium in penguins. Studies of the phylogentic relationships of these parasites will be instructive in order to understand the evolution of such host-parasite associations.

\section{Methods}

\section{Literature review}

In first reviews on infections by the main genera of haemoparasites in different bird species $[45,46]$ as well as later updates [e.g., $[13,47]]$ no data on prevalence or sample sizes were given, and many data from birds in captivity were included. In our present review (Additional file 1), we included only data of studies on wildcaught birds. We checked all the original references for this point, and references of birds of uncertain origin (e. g. bird rescue stations) were not included. Prevalence of current or past infections is measured as the proportion of individuals infected with haematozoa, recorded either by microscopic inspection of blood smears or by molecular methods that detect antibodies (ELISA) or genetic material of the haematozoa (PCR).

In the last decade, numerous studies have focused in molecular detection of blood parasitic infections in birds, mainly by amplifying DNA of the parasite by PCR [e.g., [22,48-50]], or by immunological detection of the presence of specific antibodies by ELISA [e.g., [51]]. Although these techniques are more sensitive, especially in detecting low intensity infections that may have passed unnoticed by microscopy [e.g., [52]], the small number of seabird species with molecular data available to date, does not allow comparative analyses at a broad taxonomic scale. However, we reviewed the existing literature in molecular detection of blood parasites in seabirds. There were only two cases (penguin species) that we classified as having zero prevalence of blood parasites, but that have been reported as positive using molecular techniques (Figure 1).

\section{Phylogenetically controlled analysis a) Variables and database}

In the phylogenetically controlled comparative models, we included life history and ecological variables that could explain inter-specific differences in prevalence of avian hematozoa. The variables we used were extracted from those available in reviews on bird body masses [53] and seabird biology [54]: (1) average body mass, (2) ecological parameters: (a) distribution on a scale from 1 = polar to 9 = tropical, (b) nesting habits, as either "1" for burrow or crevice nesters, or " 0 " for open nesters, including open ground, cliff, marsh or tree nesters, (c) foraging distribution on a scale from $0=$ nearshore to 2 = offshore, and (3) Life-history parameters: (a) chick developmental mode on a scale from $0=$ altricial, $1=$ semialtricial, $2=$ semiprecocial and $3=$ precocial, $(\mathrm{b})$ maximum clutch size, (c) incubation period (days) and (d) mean fledging period (days).

To control for the effect of sample size on the reliability of estimates of parasite prevalence, we restricted our comparative analyses to species for which at least 15 individuals have been sampled for blood parasites, using either blood smears [55], PCR, or both methods.

Three species (Silver gulls Larus novaehollandiae, Dolphin gulls Larus scoresbii and Little Pied cormorants Phalacrocorax melonoleucos) were excluded from the analyses, as we could not find information on all life history parameters for the analyses for these species.

The timing of blood sampling can affect the observed blood parasite prevalence in many species. Several weeks or months after infection, blood parasites can enter a latent stage, when the parasites disappear from the peripheral blood, but can persist in the internal organs. Relapses are usually synchronized with the breeding period of birds [13]. As most seabirds can only be accessed during the breeding season, the degree of parasitemia is then expected to be highest.

\section{b) Phylogeny}

We constructed a phylogenetic tree using published information on phylogenetic associations among the species of our study, in particular for Neoaves [56,57], for Sphenisciformes [58], for Procellariiformes [59-63], for Phaethontidae [64], for Pelecaniformes [65-68] and for Charadriiformes [69-77].

Because we used information from different sources and the branch lengths were not specified in all studies we used to reconstruct the phylogeny, we conducted all analyses with a tree of equal branch lengths, which assumes a punctuational model of evolution [78]. The software MESQUITE [79] was used to construct the phylogenetic tree (see tree topology in Figure 1).

\section{c) Statistical analyses}

We included all available data (from blood smears and PCR data) for each species with at least 15 sampled 
individuals. Parasite prevalences were arsin-square root transformed, while the variables body mass, clutch size, incubation and nestling period were $\log _{10}$-transformed. To control for allometric effects on parasite prevalence, average adult body mass for the species (obtained from the literature) was included in all analyses as a predictor variable. Evolutionary models were tested by Generalized Least Squares models fitted by REML, incorporating phylogenetic information with a Brownian motion correlation structure, and method (smears vs. PCR) as a variable. Model selection was based on Akaike's information criterion (AIC). All analyses were repeated using parasite prevalence as a categorical variable (presence/ absence) in phylogenetically informed Generalized Estimating Equations (GEE) models [80]. To estimate parameters of character evolution and the proportion of variance in parasite prevalence explained by phylogenetic associations among species, we computed phylogenetic autorregressions and calculated Moran's autocorrelation Index [81]. We used R 2.11.1 (R Development Core Team 2010) and the package "ape" [82] for the analyses.

\section{Additional material}

Additional file 1: Table S1. Studies of intracellular hematozoa in wild seabirds. Most studies were conducted by examination of blood smears. Any other techniques (ELISA, PCR) are detailed in the column "method" together with the target Genus (P-Plasmodium, L-

Leucocytozoon, H-Hemoproteus). Prevalence was added in brackets where known [83-143].

\section{Acknowledgements}

This work was made possible by a Synthesys grant (ES-TAF 5680). During the preparation of this work, JM and SM were supported by project CGL200909439 from the Spanish Ministry of Science and Technology, and PQ by a grant from DFG, Germany (Qu 148/1-ff). We are grateful to two anonymous referees whose comments helped to improve the ms.

\section{Author details}

${ }^{1}$ Max-Planck-Institut für Ornithologie, Vogelwarte Radolfzell, Schlossallee 2, 78315 Radolfzell, Germany. ²Departamento de Parasitología, Universidad de Alcalá, Alcalá de Henares, Spain. ${ }^{3}$ Departamento de Ecología Evolutiva, Museo Nacional de Ciencias Naturales, Consejo Superior de Investigaciones Científicas, Madrid, Spain.

\section{Authors' contributions}

PQ, JFM, JM and SM conceived and designed the study. PQ assembled the database from the literature. EA carried out the bioinformatic analyses. PQ and EA were responsible for data analysis and drafted the manuscript. JFM, JM and SM contributed to the final draft of the manuscript. All authors read and approved the final manuscript.

\section{Competing interests}

The authors declare that they have no competing interests.

Received: 11 February 2011 Accepted: 31 October 2011

Published: 31 October 2011
References

1. Sorci G, Møller AP: Comparative evidence for a positive correlation between haematozoan prevalence and mortality in waterfowl. Journal of Evolutionary Biology 1997, 10:731-741.

2. Sol D, Jovani R, Torres J: Parasite mediated mortality and host immune response explain age-related differences in blood parasitism in birds. Oecologia 2003, 135:542-547.

3. Møller AP, Nielsen JT: Malaria and risk of predation: A comparative study of birds. Ecology 2007, 88:871-881.

4. Merino S, Moreno J, Sanz JJ, Arriero E: Are avian blood parasites pathogenic in the wild? A medication experiment in blue tits (Parus caeruleus). Proceedings of the Royal Society of London Series B 2000, 267:2507-2510.

5. Sanz JJ, Arriero E, Moreno J, Merino S: Female hematozoan infection reduces hatching success but not fledging success in Pied Flycatchers Ficedula hypoleuca. Auk 2001, 118:750-755.

6. Sanz JJ, Arriero E, Moreno J, Merino S: Interactions between hemoparasite status and female age in the primary reproductive output of pied flycatchers. Oecologia 2001, 126:339-344.

7. Marzal A, de Lope F, Navarro C, Møller AP: Malarial parasites decrease reproductive success: an experimental study in a passerine bird. Oecologia 2005, 142:541-545.

8. Knowles SC, Palinauskas V, Sheldon BC: Chronic malaria infections increase family inequalities and reduce parental fitness: experimental evidence from a wild bird population. Journal of Evolutionary Biology 2010, 23:557-569.

9. Hõrak P, Ots I, Vellau H, Spottiswoode C, Møller AP: Carotenoid-based plumage coloration reflects hemoparasite infection and local survival in breeding great tits. Oecologia 2001, 126:166-173.

10. del Cerro S, Merino S, Martínez de la Puente J, Lobato E, Ruiz de Castañeda R, Rivero de Aguilar J, Martínez J, Morales J, Tomás G, Moreno J: Carotenoid-based plumage colouration is associated with blood parasite richness and stress protein levels in blue tits (Cyanistes caeruleus). Oecologia 2010, 162:825-835.

11. van Riper C III, van Riper SG, Goff ML, Laird M: The epizootiology and ecological significance of malaria in Hawaiian land birds. Ecological Monographs 1986, 56:327-344.

12. Bennett GF, Peirce MA, Ashford RW: Avian Haematozoa: mortality and pathogenicity. Journal of Natural History 1993, 27:993-1001.

13. Valkiūnas G: Avian malaria parasites and other haemosporidia CRC Press, Boca Raton, Florida; 2005.

14. Scheuerlein A, Ricklefs RE: Prevalence of blood parasites in European passeriform birds. Proceedings of the Royal Society of London Series B 2004, 271:1363-1370.

15. Arriero E, Møller AP: Host ecology and life-history traits associated with blood parasite species richness in birds. Journal of Evolutionary Biology 2008, 21:1504-1513.

16. Martinez-Abraín A, Esparza B, Oro D: Lack of blood parasites in bird species: Does absence of blood parasite vectors explain it all? Ardeola 2004, 51:225-232.

17. Valkiūnas $G$, Salaman P, lezhova TA: Paucity of hematozoa in Columbian birds. Journal of Wildlife Diseases 2003, 39:445-448.

18. Peirce MA, Brooke M: Failure to detect blood parasites in seabirds from the Pitcairn Islands. Seabird 1993, 15:72-74.

19. Merino S, Barbosa A, Moreno J, Potti J: Absence of haematozoa in a wild chinstrap penguin Pygoscelis antarctica population. Polar Biology 1997, 18:227-228.

20. Merino S, Minguez E: Absence of hematozoa in a breeding colony of the storm petrel Hydrobates pelagicus. Ibis 1998, 140:180-181.

21. Engström H, Dufva R, Olsson G: Absence of haematozoa and ectoparasites in a highly sexually ornamented species, the Crested Auklet. Waterbirds 2000, 23:486-488.

22. Quillfeldt P, Martínez J, Hennicke J, Ludynia K, Gladbach A, Masello JF, Riou S, Merino S: Hemosporidian blood parasites in seabirds-a comparative genetic study of species from Antarctic to tropical habitats. Naturwissenschaften 2010, 97:809-817.

23. Tella JL, Cortazar C, Gajon A, Osacar JJ: Apparent lack of effects of a high louse-fly infestation (Diptera, Hippoboscidae) on adult colonial alpine swifts. Ardea 1995, 83:435-439. 
24. Figuerola JA, Velarde A, Bertolero A, Cerda F: Abwesenheit von Haematozoa bei einer Brutpopulation des Seeregenpfeifers Charadrius alexandrinus in Nordspanien. Journal für Ornithologie 1996, 137:523-525.

25. Masello JF, Choconi G, Seghal RNM, Tell L, Quillfeldt P: Blood and intestinal parasites in wild Psittaciformes: a case study of Burrowing Parrots (Cyanoliseus patagonus). Ornitología Neotropical 2006, 17:515-529.

26. Bennett GF, Montgomerie R, Seutin G: Scarcity of haematozoa in birds breeding on the arctic tundra of North America. Condor 1992, 94:289-292.

27. Little RM, Earle RA: Sandgrouse (Pterocleidae) and Sociable Weavers Philetarius socius lack avian haematozoa in semi-arid regions of South Africa. Journal of Arid Environments 1995, 30:367-370.

28. Valera F, Carrillo CM, Barbosa A, Moreno E: Low prevalence of haematozoa in Trumpeter finches Bucanetes githagineus from south-eastern Spain: additional support for a restricted distribution of blood parasites in arid lands. Journal of Arid Environments 2003, 55:209-213.

29. Little RM, Earle RA: Lack of avian haematozoa in the Phaisaninae of Robben Island. Ostrich 1994, 65:343-344.

30. Piersma T: Do global patterns of habitat use and migration strategies coevolve with relative investment in immunocompetence due to spetial variation in parasites presure? Oikos 1997, 80:623-631.

31. Figuerola J: Effects of salinity on rates of infestation of waterbirds by haematozoa. Ecography 1999, 22:681-685.

32. Jovani R, Tella JL, Forero MG, Bertellotti M, Blanco G, Ceballos O, Donázar JA: Apparent absence of blood parasites in the patagonian seabird community: Is it related to the marine environment? Waterbirds 2001, 24:430-433.

33. Tella JL, Blanco G, Forero MG, Gajon A, Donazar JA, Hiraldo F: Habitat, world geographic range, and embryonic development of hosts explain the prevalence of avian hematozoa at small spatial and phylogenetic scales. Proceedings of the National Academy of Sciences of the United States of America 1999, 96:1785-1789.

34. Barbosa A, Palacios MJ: Health of Antarctic birds: a review of their parasites, pathogens and diseases. Polar Biology 2011, 32:1095-1115.

35. Merino S, Moreno J, Vásquez RA, Martínez J, Sánchez-Monsálvez I, Estades CF, Ippi S, Sabat P, Rozzi R, McGhee S: Haematozoa in forest birds from southern Chile: Latitudinal gradients in prevalence and parasite lineage richness. Austral Ecology 2008, 33:329-340.

36. Mendes L, Piersma T, Lecoq M, Spaans B, Ricklefs RE: Disease-limited distributions? Contrasts in the prevalence of avian malaria in shorebird species using marine and freshwater habitats. Oikos 2005, 109:396-404

37. Maier WA: Possible effects of climatic change on the distribution of arthropod (vector)-borne infectious diseases and human parasites in Germany. Bonn, Umweltbundesamt; 2003.

38. Martínez de la Puente J, Merino S, Lobato E, Rivero de Aguilar J, del Cerro S, Ruiz de Castañeda R, Moreno J: Does weather affect biting fly abundance in avian nests? Journal of Avian Biology 2009, 40:653-657.

39. Martínez de la Puente J, Merino S, Lobato E, Rivero de Aguilar J, del Cerro S, Ruiz de Castañeda R, Moreno J: Nest-climatic factors affect the abundance of biting flies and their effects on nestling condition. Acta Oecologica 2010, 36:543-547.

40. Allander K, Bennett GF: Prevalence and intensity of haematozoan infection in a population of Great Tits Parus major from Gotland, Sweden. Journal of Avian Biology 1994, 25:69-74.

41. Yabsley MJ, Greiner E, Tseng FS, Garner MM, Nordhausen RW, Ziccardi MH Borjesson DL, Zabolotzky S: Description of novel Babesia species and associated lesions from Common Murres (Uria aalge) from California. Journal of Parasitology 2009, 95:1183-1188

42. Greiner EC, Bennett GF, White EM, Coombs RF: Distribution of the avian hematozoa of North America. Canadian Journal of Zoology 1975, 53:1762-1787

43. Ricklefs RE, Swanson BL, Fallon SM, Martinez-Abrain A, Scheuerlein A, Gray J, Latta SC: Community relationships of avian malaria parasites in southern Missouri. Ecological Monographs 2005, 75:543-559.

44. Ricklefs RE: Embryonic development period and the prevalence of avian blood parasites. Proceedings of the National Academy of Sciences of the United States of America 1999, 89:4722-4725.

45. Bennett GF, Whiteway M, Woodworth-Lynas C: Host-parasite catalogue of avian Haematozoa. Occasional Papers in Biology, St John's, Newfoundland Canada 1982, 5:1-243.
46. Bishop MG, Bennett GF: Host-parasite catalogue of avian Haematozoa. Occasional Papers in Biology, St John's, Newfoundland Canada 1992, 15:1-209.

47. Bennett GF, Bishop MA, Peirce MA: Checklist of the avian species of Plasmodium Marchiafava \& Celli, 1885 (Apicomplexa) and their distribution by avian family and Wallacean life zones. Systematic Parasitology 1993, 26:171-179.

48. Perkins SL, Schall JJ: A molecular phylogeny of malarial parasites recovered from cytochrome b gene sequences. Journal of Parasitology 2002, 88:972-978.

49. Waldenström J, Bensch S, Hasselquist D, Östman Ö: A new nested polymerase chain reaction method very efficient in detecting Plasmodium and Haemoproteus infections from avian blood. Journal of Parasitology 2004, 90:191-194.

50. Hill AG, Howe L, Gartrell BD, Alley MR: Prevalence of Leucocytozoon spp, in the endangered yellow-eyed penguin Megadyptes antipodes. Parasitology 2010, 137:1477-1485.

51. Graczyk TK, Cockrem JF, Cranfield MR, Darby JT, Moore P: Avian malaria sero-prevalence in wild New Zealand penguins. Parasite - Parasite-Journal de la Societe Francaise de Parasitologie 1995, 2:401-405.

52. Fallon SM, Ricklefs RE: Parasitemia in PCR-detected Plasmodium and Haemoproteus infections in birds. Journal of Avian Biology 2008, 39:514-522.

53. Dunning JB Jr: Avian Body Masses. 2 edition. Boca Raton: CRC Press; 2008.

54. Schreiber EA, Burger J: Biology of marine birds Boca Raton: CRC Press; 2001

55. Jovani $R$, Tella JL: Parasite prevalence and sample size: misconceptions and solutions. Trends in Parasitology 2006, 22:214-218.

56. Hackett SJ, Kimball RT, Reddy S, Bowie RCK, Braun EL, Braun MJ, Chojnowski JL, Cox WA, Han K-L, Harshman J, Huddleston CJ, Marks BD, Miglia KJ, Moore WS, Sheldon FH, Steadman DW, Witt CC, Yuri T: A phylogenomic study of birds reveals their evolutionary history. Science 2008, 320:1763-1768

57. Ericson PGP, Anderson CL, Britton T, Elzanowski A, Johansson US, Källersjö M, Ohlson Jl, Parsons TJ, Zuccon D, Mayr G: Diversification of Neoaves: integration of molecular sequence data and fossils. Biology Letters 2006, 2:543-547.

58. Bertelli S, Giannini NP: A phylogeny of extant penguins (Aves: Sphenisciformes) combining morphology and mitochondrial sequences. Cladistics 2005, 21:209-239.

59. Nunn GB, Stanley SE: Body size effects and rates of cytochrome b evolution in tube-nosed seabirds. Molecular Biology and Evolution 1998, 15:1360-1371.

60. Bretagnolle $\mathrm{V}$, Attié $\mathrm{C}$, Pasquet E: Cytochrome-B evidence for validity and phylogenetic relationships of Pseudobulweria and Bulweria (Procellariidae). Auk 2011, 115:88-195.

61. Austin JJ, Bretagnolle $\mathrm{V}$, Pasquet E: A global molecular phylogeny of the small Puffinus shearwaters and implications for systematics of the LittleAudubon's shearwater complex. Auk 2004, 121:847-864.

62. Penhallurick J, Wink M: Analysis of the taxonomy and nomenclature of the Procellariiformes based on complete nucleotide sequences of the mitochondrial cytochrome b gene. Emu 2004, 104:125-147.

63. Rheindt FE, Austin JJ: Major analytical and conceptual shortcomings in a recent taxonomic revision of the Procellariiformes - a reply to Penhallurick and Wink (2004). Emu 2005, 105:181-186.

64. Kennedy M, Spencer HG: Phylogenies of the frigatebirds (Fregatidae) and tropicbirds (Phaethontidae), two divergent groups of the traditional order Pelecaniformes, inferred from mitochondrial DNA sequences. Molecular Phylogenetics and Evolution 2004, 31:31-38.

65. Kennedy M, Spencer HG, Gray RD: Hop, step and gape: do the social displays of the Pelecaniformes reflect phylogeny? Animal Behaviour 1996, 51:273-291.

66. Friesen VL, Anderson DJ: Phylogeny and evolution of the Sulidae (Aves: Pelecaniformes): a test of alternative modes of speciation. Molecular Phylogentics and Evolution 1997, 7:252-260.

67. Kennedy M, Gray RD, Spencer HG: The phylogenetic relationships of the shags and cormorants: can sequence data resolve a disagreement between behavior and morphology? Molecular Phylogenetics and Evolution 2000, 17:345-359.

68. Friesen VL, Anderson DJ, Steeves TE, Jones H, Schreiber EA: Molecular support for the species status of the Nazca Booby (Sula granti). Auk 2002, 119:820-826 
69. Cohen BL, Baker AJ, Blechschmidt K, Dittmann DL, Furness RW, Gerwin JA Helbig AJ, De Korte J, Marshall HD, Palma RL, Peter H-U, Ramli R, Siebold I, Willcox MS, Wilson RH, Zink RM: Enigmatic phylogeny of skuas (Aves: Stercorariidae). Proceedings of the Royal Society of London Series B 1997, 264:181-190.

70. Crochet P-A, Bonhomme F, Lebreton JD: Molecular phylogeny and plumage evolution in gulls (Larini). Journal of Evolutionary Biology 2000, 13:47-57.

71. Paton TA, Baker AJ, Groth JG, Barrowclough GF: RAG-1 sequences resolve phylogenetic relationships within Charadriiform birds. Molecular Phylogenetics and Evolution 2003, 29:268-278.

72. Fain $\mathrm{MG}$, Houde P: Parallel radiations in the primary clades of birds. Evolution 2004, 58:2558-2573.

73. Thomas GH, Wills MA, Szekely T: Phylogeny of shorebirds, gulls, and alcids (Aves: Charadrii) from the cytochrome-b gene: Parsimony, Bayesian inference, minimum evolution, and quartet puzzling. Molecular Phylogenetics and Evolution 2004, 30:516-526.

74. Bridge $E S$, Jones AW, Baker AJ: A phylogenetic framework for the terns (Sternini) inferred from mtDNA sequences: Implications for taxonomy and plumage evolution. Molecular Phylogenetics and Evolution 2005, 35:459-469.

75. Pons J-M, Hassanin A, Crochet P-A: Phylogenetic relationships within the Laridae (Charadriiformes: Aves) inferred from mitochondrial markers. Molecular Phylogenetics and Evolution 2005, 37:686-699.

76. Baker AJ, Pereira SL, Paton TA: Phylogenetic relationships and divergence times of Charadriiformes genera: multigene evidence for the Cretaceous origin of at least 14 clades of shorebirds. Biology Letters 2007, 3:205-209.

77. Pereira SL, Baker AJ: DNA evidence for a Paleocene origin of the Alcidae (Aves: Charadriiformes) in the Pacific and multiple dispersals across northern oceans. Molecular Phylogenetics and Evolution 2008, 46:430-445.

78. Harvey PH, Pagel MD: The comparative method in evolutionary biology Oxford: Oxford University Press; 1991.

79. Maddison W, Maddison D: MESQUITE 1997 [http://mesquiteproject.org]

80. Paradis E: Analysis of Phylogenetics and Evolution with R New York: Springer; 2006.

81. Diniz-Filho JAF: Phylogenetic autocorrelation under distinct evolutionary processes. Evolution 2001, 55:1104-1109.

82. Paradis E, Claude J, Strimmer K: APE: analyses of phylogenetics and evolution in R language. Bioinformatics 2011, 20:289-290.

83. Becker CD, Holloway HL: A survey for haematozoa in Antarctic vertebrates. Trans Am Microsc Soc 1968, 87:354-360.

84. Jones HI, Shellam GR: The occurrence of blood-inhabiting protozoa in captive and free-living penguins. Polar Biol 1999, 21:5-10.

85. Jones HI: Notes on Parasites in Penguins (Spheniscidae) and Petrels (Procellariidae) in the Antarctic and Sub-antarctic. Journal of Wildlife Diseases 1988, 24:166-167.

86. Peirce MA, Prince PA: Hepatozoon albatrossi sp.nov. (Eucoccidia Hepatozoidae) from Diomedea spp. in the Antarctic. Journal of Natural History 1980, 14:447-452.

87. Laird M: Protozoological studies at Macquarie Island. Trans Roy Soc New Zealand 1952, 79:583-588.

88. Karesh WB, Uhart MM, Frere E, Gandini P, Braselton WE, Puche H, Cook RA: Health evaluation of free-ranging rockhopper penguins (Eudyptes chrysocome) in Argentina. J Zoo Wildlife Med 1999, 30:25-31.

89. Graczyk TK, Cockrem JF, Cranfield MR, Darby JT, Moore P: Avian malaria sero-prevalence in wild New Zealand penguins. Parasite - J Soc Fr Parasitol 1995, 2:401-405

90. Schultz A, Petersen SL: Absence of haematozoa in breeding macaroni Eudyptes chrysolophus and rockhopper E. chrysocome penguins at Marion Island. Afr J Mar Sci 2003, 25:499-502.

91. Fantham $\mathrm{HB}$, Porter $\mathrm{A}$ : On a Plasmodium (Plasmodium relictum var. spheniscidae n. var.) observed in four species of penguins. Proc Zool Soc Lond 1944, 114:279-292.

92. Fallis AM, Bisset SA, Allison FR: Leucocytozoon tawaki n. sp. (Eucoccida: Leucocytozoidae) from the penguin Eudyptes pachyrhynchus, and preliminary observations on its development in Austrosimulium spp. New Zealand J Zool 1976, 3:11-16.

93. Laird M: Some blood parasites of New Zealand birds. Zool Pub Victoria Univ College 1950, 5:1-20

94. Jones HI, Woehler EJ: A new species of blood trypanosome from Little Penguins (Eudyptula minor) in Tasmania. J Protozool 1989, 36:389-390.
95. Peirce MA: A taxonomic review of avian piroplasms of the genus Babesia Starcovici, 1893 (Apicomplexa: Piroplasmorida: Babesiidae). J Nat Hist 2000, 34:317-332.

96. Mykytowycz R, Hesterman ER: A note on tick infestation of the fairy penguin, Eudyptula minor. CSIRO Wildlife Research 1957, 2:165-166.

97. Sturrock HJW, Tompkins DM: Avian malaria parasites (Plasmodium spp.) in Dunedin and on the Otago Peninsula, southern New Zealand. New Zealand J Ecol 2008, 32:98-102.

98. Laird M: A lack of avian and mammalian haematozoa in the Antarctic and Canadian Arctic. Canad J Zool 1961, 39:209-213.

99. Brossy J-J: Malaria in wild and captive Jackass Penguins Spheniscus demersus along the southern African coast. Ostrich 1992, 63:10-12.

100. Wallace RS, Teare JA, Diebold E, Michaels M, Willis MJ: Hematology and plasma chemistry values in free-ranging Humboldt penguins Spheniscus humboldti in Chile. Zoo Biol 1995, 14:311-316.

101. Miller GD, Hofkin BV, Snell H, Hahn A, Miller RD: Avian malaria and Marek's Disease: potential threats to Galapagos Penguins Spheniscus mendiculus. Mar Orn 2001, 29:43-46.

102. Parker PG, Whiteman NK, Miller RE: Conservation medicine on the Galápagos islands: partnerships among behavioral, population, and veterinary scientists. Auk 2006, 123:625-638

103. Levin II, Outlaw DC, Vargas FH, Parker PG: Plasmodium blood parasite found in endangered Galapagos penguins (Spheniscus mendiculus). Biol Conserv 2009, 142:3191-3195.

104. McKenna PB: Register of new host-parasite records. Surveillance 2005, 32:7-8.

105. Work TM: Weight, hematology, and serum chemistry of seven species of free-ranging tropical pelagic seabirds. J Wildl Dis 1996, 34:643-657.

106. Padilla LR, Huyvert KP, Merkel J, Miller RE, Parker PG: Hematology, plasma chemistry, serology, and Chlamydophila status of the Waved Albatross (Phoebastria irrorata) on the Galapagos Islands. J Zoo Wildl Med 2003, 34:278-283.

107. Wink M, Wink C, Ristow D: Parasitenbefall juveniler und adulter Gelbschnabelsturmtaucher (Calonectris diomedea). Bonn Zool Beitr 1979, 30:217-219.

108. Gonzáles-Solís J, Abella JC: Negative record of haematozoan parasites on Cory's shearwater Calonectris diomedea. Ornis Fennica 1997, 74:153-155.

109. Peirce MA: A survey of blood parasites of birds in the Mascarene Islands, Indian Ocean: with descriptions of two new species and taxonomic discussion. Ibis 1977, 119:451-461.

110. Warner RE: The role of introduced diseases in the extinction of the endemic Hawaiian avifauna. Condor 1968, 70:101-120.

111. Simons TR: Biology and behavior of the endangered Hawaiian Darkrumped petrel. Condor 1985, 87:229-245.

112. Clark GW, Swinehart B: Avian haematozoa from the offshore islands of northern Mexico. Bull. Wildlife Disease Assoc 1969, 5:111-112.

113. Peirce MA: Haematozoa of British birds. VI. Redescription of Haemoproteus larae Yakunin from the lesser black-backed gull Larus fuscus. Journal of Natural History 1981, 15:459-462.

114. Esparza B, Martínez-Abraín A, Merino S, Oro D: Immunocompetence and the prevalence of haematozoan parasites in two long-lived seabirds. Ornis Fennica 2004, 81:40-46.

115. Lowery RS: Blood parasites of vertebrates on Aldabra. Phil Trans R Soc Lond B 1971, 260:577-580.

116. Zaias J, Fox WP, Cray C, Altman NH: Hematologic, plasma protein, and biochemical profiles of brown pelicans (Pelecanus occidentalis). J Vet Res 2000, 61:771-774.

117. Peirce MA, Feare CJ: Piroplasmosis in the Masked Booby Sula dactylatra melanops in the Amirantes, Indian Ocean. Bull British Ornithol Club 1978, 98:38-40.

118. Work TM, Rameyer RA: Description and epizootiology of Babesia poelea $n$. $s p$. in Brown Boobies (Sula leucogaster (Boddaert)) on Sand Island, Johnston Atoll, Central Pacific. J Parasitol 1997, 83:734-738.

119. Padilla LR, Whiteman NK, Merkel J, Huyvert KP, Parker PG: Health assessment of seabirds on Isla Genovesa, Galápagos. Ornithol Monogr 2006, 60:86-97.

120. Bennett GF, Aguirre AA, Cook RS: Blood parasites of some birds from northeastern Mexico. J Parasitol 1991, 77:38-41.

121. Love GJ, Wilkin SA, Goodwin MH: Incidence of blood parasites in birds collected in Southwestern Georgia. J Parasitol 1953, 39:52-57. 
122. Mackerras MJ, Mackerras IM: The haematozoa of Australian birds. Austr J Zool 1960, 8:226-260

123. Madsen V, Dabelsteen T, Osorio D, Osorno JL: Morphology and ornamentation in male magnificent frigatebirds: Variation with age class and mating status. Am Nat 2007, 169:S93-S111.

124. Work TM, Rameyer RA: Haemoproteus iwa n. sp. in Great Frigatebirds (Fregata minor [Gmelin]) from Hawaii: parasite morphology and prevalence. J Parasitol 1996, 82:489-491.

125. Jones HI, Gallagher JM, Miller GD: Survey of South Polar Skuas (Catharacta maccormicki) for blood parasites in the Vestfold Hills region of Antarctica. J Wildl Dis 2002, 38:213-215.

126. Bearhop S, Griffith R, Orr K, Furness RW: The normal haematology of Great Skuas (Catharacta skua) in the wild. Comp Haematol Int 1999, 9:107-109.

127. Franchini G: Observations sur les hematozoaires des oiseaux d'Italie. Ann. Inst. Pasteur, Paris; 1924:38:470-515.

128. Coatney GR: Some Blood Parasites from Birds of the Lake Okaboji Region. Am Midl Nat 1938, 20:336-340.

129. Mandal FB, Nandi NC, Mandal AK: Incidence of haemoparasites in some Indian birds. Indian J. Anim Health 1989, 28:33-38.

130. Peirce MA: Haematozoa of African birds: some miscellaneous findings. Afr J Ecol 1984, 22:149-152

131. Bosch M, Figuerola J, Cantos FJ, Velarde R: Intracolonial differences in the infestation by Haemoproteus lari on Yellow-legged Gulls Larus cachinnans. Ornis Fennica 1997, 74:105-112.

132. Ruiz X, Oro D, Gonzales-Solis J: Incidence of a Haemoproteus lari parasitemia in a threatened Gull Larus audouinii. Ornis Fennica 1995, 72:159-164.

133. Martínez-Abraín A, Merino S, Oro D, Esparza B: Prevalence of blood parasites in two western-Mediterranean local populations of the Yellowlegged Gull Larus cachinnans michahellis. Ornis Fennica 2002, 79:34-40.

134. Merino S: Babesia bennetti n.sp. from the Yellowlegged Gull (Larus cachinnans, Aves, Laridae) on Benidorm Island, Mediterranean Sea. J Parasitol 1998, 84:422-424.

135. Genbank Accession Number EF380176. [http://www.ncbi.nlm.nih.gov/ nuccore/148469775].

136. Hoberg EP: Eulimdana rauschomm n. sp., a filarioid nematode (Lemdaninae) from Larus dominicanus in Antarctica, with comments on evolution and biogeography. J Parasitol 1986, 72:755-761.

137. Shamsuddin M, Mohammad MK: Haematozoa of some Iraqi birds with description of two new species, Haemoproteus pteroclis and Leucocytozoon nycticoraxi (Protozoa: Haemosporina). Bull Nat Hist Res Centre, Baghdad; 1981:7:111-154.

138. Berdyev KS: K faune kroveparazitov dikikh ptits Yuzhnogo Turkmenistana. (In Russian) [Blood parasites of wild birds in South Turkmenistan]. Razvitie Parazitologicheskoi Naukiv Turkmenistane, Ashkhabad; 1979, 156-162.

139. Kairullaev KK: Blood parasites (Haemoproteus Kruse, 1890) in birds of Kazakh-SSR, USSR. Izv. Akad Nauk Kaz SSR Ser Biol Nauk 1986, 39-42.

140. Peirce MA: Distribution and host-parasite check-list of the haematozoa of birds in Western Europe. Journal of Natural History 1981, 15:419-458.

141. Fiorello CV, Nisbet ICT, Hatch JJ, Corsiglia C, Pokras MA: Hematology and absence of hemoparasites in breeding Common Terns (Sterna hirundo) from Cape Cod, Massachusetts. Journal of Zoo and Wildlife Medicine 2009 40:409-413.

142. Engström H, Dufva R, Olsson G: Absence of haematozoa and ectoparasites in a highly sexually ornamented species, the Crested Auklet. Waterbirds 2000, 23:486-488.

143. Wojczulanis-Jakubas K, Svoboda A, Kruszewicz A, Johnsen A: No Evidence of Blood Parasites in Little Auks (Alle alle) Breeding on Svalbard. Journal of Wildlife Diseases 2010, 46:574-578.

doi:10.1186/1742-9994-8-26

Cite this article as: Quillfeldt et al:: Prevalence of blood parasites in seabirds - a review. Frontiers in Zoology 2011 8:26.

\section{Submit your next manuscript to BioMed Central and take full advantage of:}

- Convenient online submission

- Thorough peer review

- No space constraints or color figure charges

- Immediate publication on acceptance

- Inclusion in PubMed, CAS, Scopus and Google Scholar

- Research which is freely available for redistribution

Submit your manuscript at www.biomedcentral.com/submit
Biomed Central 